of attainment or conferring more éolat in the public eye then the College will cease to be what it still is, its revenues and its prestige will decline, and those who have accomplished its fall will be those who sit and listen with such an aspect of polite boredom to the voteless if not voiceless expression of the Members' discontent. Surely the granting of a new charter is the best occasion for a consideration of all claims that should find their place therein, and despite the President's pathetic appeal the blame for any dashing of his hopes must rest on those of the Council who have delayed till the eleventh hour the promulgation of the draft, doubtless in order to baulk any practical embodiment of the Members' rights therein.

I am, Sirs, yours faithfully,

WM. J. TOWNSEND BARKER, M.R.C.S. Eng., L.R.C.P., L.S.A. Lond., D.P.H. Cantab.,

Formerly Physicians' Assistant, Bristol General Hospital, and Clinical Assistant, Bristol Eye Hospital, \&e.

Fulham, S.W., July 10th, 1899 .

\section{THE NOTIFICATION OF INFECTIOUS DISEASE AND UNQUALIFIED PRACTITIONERS.}

To the Editors of THH LANCET.

SIRS,-I should like to bave your opinion on the following which has come under my notice as chairman of the Sanitary Committee here. A medical man in this district was called in to see a case and found the patient suffering from scarlatinal nephritis and the skin peeling. He asked who had been attending the child previously and was informed that a herbalist had been seeing the child at his shop for the last two weeks. In sending a notification of the disease to the council he reported that the herbalist had the case under hand previously to himself. We have had no notification from the herbalist. According to the Notification of Infectious Diseases Act ought the herbalist to have reported the case? and can we as a sanitary authority take any action in the matter? There is nothing, I presume, to prevent herbalists from treating cases of scarlet fever if the patient or his guardian so desires it, but are we as a sanitary authority to impose a fine on registered practitioners for not notifying and allow herbalists to do the same without any interference on our part?

I remain, Sirs, yours faithfully,

E. A. Clarke, M.R.C.S. Eng., L.S.A.

Dukinfield, June 28th, 1899.

*** There is, as our correspondent implies, no power to prevent persons from employing unqualified practitioners such as herbalists, but the law has decided that risk to public health shall not be incurred by reason of the non-notification of cases of infectious diseases in such instances. Hence it is that the Infectious Disease (Notification) Act, 1889, provided for dual notification, and in Clause 3 (1) $a$ there is a definite obligation on the head of the family to send the required notice to the medical officer of health. Clearly the head of the family who fails in this duty when he avoids employing a qualified medical practitioner should be proceeded against. In the absence of such proceedings unqualified attendance would soon be sought merely to avoid notification and thus to prevent the intervention of the sanitary officers in the interests of the public health.-ED. L.

\section{"THE ROYAL ARMY MEDICAL CORPS MANUAL."}

To the Editors of THE LANOET.

SIRs,-The amount of publicity given in the medical and volunteer papers to Surgeon-Captain Sleman's suggestion seemed to imply that it was at least something original. Now it appears that all he can claim is to have suggested a method which has been practically common property for several years. Wbatever credit may be attached to this by all means let him have.

July 11th, 1899.

$$
\text { I am, Sirs, yours faithfully, }
$$
VALENTINE MatTHeWs.

To the Editors of THW LANCET.

SiRs,-That the Volunteer Ambulance School of Instruction submitted to the authorities the scheme of lifting wounded now promulgated in the Royal Army Medical Corps Manual is no doubt true and our thanks are due to them for it, but I can bear out Mr. Valentine Matthews's statement that the method is no new one and has been for years discuss $d$ by medical officers of volunteers. It is practically the same as that adopted by the American army as far back as 1892 and must surely have been known to our medical staff. This method is so obviously the most simple and strajghtforward. that it has been a surprise to those of us engaged in teaching stretcher drill that any other could be adopted. The late mode of lifting wounded was probably a relic of the days of petty and complicated mancuvres.

I am, Sirs, yours faithfully,

July 11th, 1899. A Medical OfFICER OF VOLUnterers.

\section{"CHINOSOL I N PHTHISIS." \\ To the Editors of THE LANCET.}

SIRS,-With reference to Dr. Macgregor's article on the chinosol treatment in pulmorary phthisis, it would be interesting to know whether in those cases which he mentioned had undergone the above treatment he had confirmed his diagnosis by a bacteriological search for the tubercle bacillus apart from physical signs and symptoms.

I am, Sirs, yours faithfully,

Great Yarmoutb, July 8th, 1899. JOHN R. O'BRIEN.

\section{THE PATHOLOGY OF CANCER : A DISCLAIMER. \\ To the Editors of THE LANCET.}

SIRs,-I trust you will be able to grant me a little space in your valuable journal as I wish to take the earliest opportunity of disclaiming any association with the paragraphs relating to me recently appearing in the daily papers. These paragraphs are in many respects misleading and are calculated to delude unfortunate sufferers by holding out false hopes and to bring me into discredit amongst my professional brethren. A short account of my experiments on cancer will appear in the forthcoming number of the Junrnat of Pathology, but as this premature publicity bas occurred perhaps you will allow me to state briefly the reai facts of the case. I have been long impressed by the following considerations-viz., that the epitbelial cells of cancer were themselves the sole infective agents; that this cancer epithelium was practically normal epitbelium, only out of place; and that from the very commencement of the cancer it was growing in the lymph spaces. I thought from this that if the normal epithelium by some accidental means should obtain entrance into the lymph spaces it would find no barrier to its continued growth and would produce all the phenomena of cancer. At present I bave performed but a single experiment to test this view. I obtained an emulsion of the epithelial cells from the healthy ovary of a healthy rabbit and placed them in the animal's peritoneum. The animal died 14 months afterwards and on examination masses of growth were found in the abdominal and thoracic cavities having the characteristic features of typical ovarian cancer. Experiments will be carried out to confirm and extend these results and until these have been completed no general conclusions can be drawn. Apologising for the length of this communication,

I am, Sirs, yours faithfully,

Harley-street, W. July 7th, 1899 . H. LAMBERT LACK.

\section{"THE REMOVAL OF OUTGROWTHS FROM THE NASAL SEPTUM, ETC." To the Editors of THE LaNCET.}

SIRs,-To answer fully the very practical questions of "An Exile" would require more of your space than, I fear, you are able to afford. Outgrowths from the nasal septum other than "spurs" are rare, and should always be removed because of a certain liability to take on malignant transformation. No unpleasant result is likely to follow provided that chemical cauterisation is employed for destruction of their base, or of any fragment remaining after use of snare or knife. The galvano-cautery is, however, to be avoided from its tendency to form scar tissue on the septum leading to " bridging." In any case it is well to employ an ivory 
shield to the external wall of the nostril and to use great care in the application of whatever caustic may be selected. The indication which I have laid down for the removal of a "spur" is whether or not it is in constant contact with the opposite inferior turbinal. It is certainly better to reduce bypertrophy of the turbinal first either by cautery or by turbinotome (Carmalt Jones's spokeshave) but occasionally when the spur is very large this should first be attacked.

* As to tonsils I have employed no other instrument than the guillotine in an extensive experience of over 30 years except in the rare instances of extreme enlargement or a hæmorrhagic tendency, when a wire ecraseur is preferable. It may be useful to add that in all cases of enlarged tonsils in children under the age of 15 adenoids should be searched for and if found removed at the same sitting.

I am, Sirs, yours faithfully,

Mansfield-street, W., July 5th, 1899. LENNOX BROWNE.

\section{NASAL DIPHTHERIA.}

\section{To the Eators of THE LANCET.}

SIRs, - I should be glad of any advice from you or any of your readers on the following case in which $I$ am much interested. A youth of 13 years is the subject of KlebsLöfler bacillus in the nose but otherwise seems to be in excellent health. About the beginning of May this year he contracted measles at a public school. This was of a mild description and soon passed off, but a slight soreness about one nostril attracted attention and an examination of a specimen of the nasal discharge revealed Klebs-Löffler bacilli in abundance. On this account he was isolated for some weeks, but as the bacillus still remained he was remored to his home.

There was no constitutional disturbance whatever and at present he is in excellent health, although from a further bacteriological examination since he came home the bacillus remains. What I am anxious to know is how it is to be got rid of and what is its significance? If sent back to school would it be at the risk of giving other pupils a similar complaint? Why, if this is the genuine diphtheria bacillus, does it give rise to no grave symptoms or, in fact, to no constitutional symptoms at all? Anxiously awaiting any information which may throw more light on the subject,

Gosport, July 5th, 1899. I am, Sirs, yours faithfully,

** The exact significance of cases of this nature is not at present understood. Bacilli not to be distinguished in virulence or morphologically from the Klebs-Löffler bacillus have several times been identified in the discharge of postscarlatinal rhinitis. The organism found in this case should be submitted to further investigation with the object of placing its identity beyond doubt. Thorough irrigation of the nostrils with 1 in 2000 solution of perchloride of mercury should be carried out every few hours and if thoroughly done should result in the disappearance of the bacillus within 10 days. It is not desirable that the boy should return to school before the local trouble has been cured.ED. L.

\section{PUBLIC VEHICLES AND INFECTION. To the Editors of THE LANOE'T.}

SIRs, - I was riding the other day icside an omnibus belonging to one of the large London companies when I witnessed the following incident. A child sitting on the Iznee of its mother, a woman of the working classes, coughed and choked. In an instant the conductor who was descending from the roof ran down the remaining steps and sternly asked the woman, "Has that child whooping-cough?" Reluctantly and resentfully she admitted that it had. "Then take it outside," said the conductor, and without directly questioning his authority, although unwillingly, she did so the next time the vehicle paused to set down passengers. I confess to having been a little surprised at the rapidity of the conductor's diagnosis, the masterfulness of his method, and the obedience of the mother-and a little sorry for the child. while at the same time I should like to know what discretion there is, or authority, to remove anyone with such a complaint from an omnibus, and whether I can another time if I suspect a child of suffering from anything like whoopingcough insist on the conductor investigating the matter and taking steps for the removal of the invalid.

July 4th, 1899.

I am, Sirs, yours faithfully, VIATOR.

PS.-I enclose an extract from the Daily Cleronicle of June 30th which shows that indifference to the risk of infecting others is not confined to what are sometimes called the "lower orders."

Tratexltag with THE Whoopirg-COUgh.--A Bournemouth correspondent thinks, very properly, that something should be done to stop the trarelling in public conveyances of persons suffering from infectious diseases. His wife and two children were going to London the other day, the children on their way to their respectire schools, and at Southampton a lady and a child entered the compartment. After the train had started, not to stop again before it reached London, the child had a violent paroxysm of whooping-cough, so that the other two children were exposed to the infection all the way to London, as there was no opportunity of changing. Our correspondent wonders whether such a case would justity the stopping of the train by pulling the cord, It ought to.

\section{"THE METROPOLITAN PROVIDENT IIEDICAL ASSOCIATION." \\ To the Editors of THE LANCET.}

SIRS,- $\mathrm{It}$ is suggested in an annotation in THE LANCET of July 8th on the work of the Metropolitan Provident Medical Association that the sum of $£ 641$ (the difference between the payments of the benefit members of the association and the amount paid to the medical officers) might in future be paid to the medical officers. May I explain that this sum represents the maintenance and cost of the dispensaries and the cost of the drugs.

I am, Sirs, your faithfully,

The Treascrer of The Metropolitan Provident MEDiCAL ASSOCTATION.

Lamlis Conduit-street, July 11th, 1899.

ERRATA.-In our issue of June 10th there appeared a letter signed "A. H. Choksy." It should have been signed N. H. Choksy. Also in line 24 of the letter the word "assist" should have been "insist."

\section{NOTES FROM INDIA.}

\section{(FROM OUR SPECIAL CORRESPONDENT.)}

Inoculation for Enteric Fever.-The Crusade against Mosquitocs.- The Progress of the Plague.-The Report on the Outbreak at Bangalore.

THE Secretary of State has sanctioned the resumption of voluntary inoculation against enteric fever which, it will be remembered, was instituted during the visit of Professor Wright to India while acting on the Plague Commission. It is difficult to understand why it was suspended, as so far as it has been tried it has given promise ef protection. This form of fever bas been terribly on the increase. Before 1880 the death-rate in the British Army of India was only 2.03 per 1000. In the 10 years ending 1890 it rose to 3.79 per 1000. In 1896 the mortality was 631 per 1000, and in 1897 it was no less than 9.01 per 1000 . Enteric fever thus caused more than a third of the total deaths. The loss of 616 young: soldiers' lives in one year is a very serious matter, especially when it indicates that there were 297 men constantly sick from this disease and that the average duration of a case was 53 days. Besides the waste of life the total loss of service is enormous. The death-rate at Agra was no less than 4504 per 1000, and at Mhow, Meerut, and Peshawar it exceeded 16 per 1000 . Considering the liability of the youngest soldiers, and especially those newly arrived in India, to contract this disease it is incumbent upon the authorities to urge the adoption of protective inoculation in every possible way. Compared with enteric fever the dangers of small-pox are infinitesimal, and considering the special dangers in India and the fatality of the disease here it is reasonable that the opportunities of protective inoculation should be offered to every soldier before he embarks for this country.

Orders issued by the Government of India to civil surgeons with entomological proclivities require them "to make collections of mosquitoes and other flies that bite men or animals 